\title{
Działalność Towarzystwa Miłośników Torunia w okresie od 25 maja 2018 r. do 16 maja 2019 r.
}

\author{
http://dx.doi.org/10.12775/RT.2019.010
}

\section{Członkowie Towarzystwa}

Towarzystwo Miłośników Torunia liczy obecnie 131 członków, z czego w kole śródmiejskim 115 osób, a w sekcji krótkofalowców 16. W okresie sprawozdawczym do Towarzystwa przystąpiły cztery osoby: Michał Józefowicz, Maria Mameła, Urszula Walczewska, Stanisław Walczewski. Z grona członków i działaczy Towarzystwa odeszli m.in.:

- 27 sierpnia 2018 r. Michał Staśkiewicz, 77 lat, zasłużony działacz kultury, pracownik samorządu toruńskiego, wieloletni naczelnik Wydziału Kultury, autor publikacji ToMiTo,

- 3 stycznia 2019 r. redaktor Zefiryn Jędrzyński, 88 lat, dziennikarz i publicysta, długoletni, zaangażowany członek ToMiTo, autor i redaktor wydawnictw Towarzystwa, redaktor naczelny „Nowości” i „Gazety Pomorskiej”, działacz kultury,

- 15 stycznia 2019 r. redaktor Stanisław Frankowski, 74 lata, bibliofil, miłośnik Torunia i Kujaw, przez ponad 40 lat dziennikarz „Nowości”, redaktor wielu druków bibliofilskich, od 1968 r. członek i przyjaciel ToMiTo, często pisał o wydawnictwach Towarzystwa i zasłużonych ludziach Torunia,

- 29 stycznia 2019 r. Ludmiła Stadnicka-Kozłowska, 72 lata, przewodnicząca Koła ToMiTo na Podgórzu.

\section{Walne Zebranie i władze Towarzystwa}

Na Walnym Zebraniu Sprawozdawczo-Wyborczym w dniu 25 maja 2017 r. wybrano nowe władze Towarzystwa. Zarząd tworzą: prezes i redaktor „Toruńskiego Słownika Biograficznego" Krzysztof Mikulski, wiceprezesi - Piotr Oliński, Michał Targowski, sekretarz - Katarzyna Tomkowiak, skarbnik - 
Piotr Birecki, przewodniczący sekcji historycznej - Krzysztof Kopiński, przewodniczący sekcji łączności z mediami - Wiesław Nowosad, przewodniczący sekcji do spraw wizerunku miasta - Roman Spandowski, przewodniczący sekcji krótkofalowców - Mariusz Thomas, przewodnicząca sekcji wydawniczej i redaktor „Rocznika Toruńskiego” - Agnieszka Zielińska, członkowie Zarządu: Cecylia Iwaniszewska, Jarosław Kłaczkow, Kamila Maj, Sławomir Pułkownik, Andrzej Szmak, Jolanta Wasiewska. Na wniosek Jolanty Wasiewskiej, w kwietniu 2019 r., po śmierci przewodniczącej Koła Podgórz Ludmiły Stadnickiej-Kozłowskiej, działalność Koła zawieszono. Komisję Rewizyjną Towarzystwa tworzą: przewodnicząca - Stefania Sieracka, członkowie: Jacek Tylicki, Andrzej Warot. W okresie sprawozdawczym Zarząd zbierał się sześć razy na zebraniach protokołowanych (w tym jedno posiedzenie miało charakter okolicznościowy - noworoczny), a Prezydium spotykało się częściej dla załatwienia bieżących spraw. Komisja Rewizyjna w dniu 7 maja 2019 r. oceniała działalność Zarządu. Skład Prezydium i Zarządu Towarzystwa nie zmienił się w okresie sprawozdawczym, zawieszono jedynie działalność Koła Podgórz. Biuro Towarzystwa, jak i księgowość prowadzi pracująca na pół etatu Joanna Danuta Horyza. Biuro mieści się w budynku przy ul. Podmurnej 60, należącym do Gminy Miasta Toruń. Towarzystwo użytkuje tam pomieszczenie biurowe na I piętrze o powierzchni $21,35 \mathrm{~m}^{2}$. Ryczałtowa opłata miesięczna za media wynosi $350 \mathrm{zł}$. Biblioteka Towarzystwa, licząca obecnie 687 tomów, oraz wszystkie wydawnictwa znajdują się w tym samym pomieszczeniu biurowym. Witryną internetową Towarzystwa zajmują się Wiesław Nowosad i Joanna Horyza. Strona dostępna jest pod adresem: www.tomito.cba.pl.

\section{Działalność Towarzystwa}

Od wielu lat działalność Towarzystwa Miłośników Torunia na rzecz miasta Torunia obejmuje następujące dziedziny: współdziałanie z władzami miasta, popularyzowanie wiedzy o Toruniu oraz wydawanie publikacji związanych z jego dziejami.

\section{Współdziałanie z władzami miasta}

Do corocznego konkursu „Toruń w kwiatach” zgłoszono 77 balkonów i ogródków przydomowych, które poddano ocenie. Komisja przyznała 29 pierwszych miejsc, 42 drugie, 5 trzecich, a 3 osoby otrzymały nagrodę prezydenta miasta Torunia statuetkę „Flisaka”. Komisja konkursowa działała w składzie: Elżbieta Thomas przewodnicząca, Ludmiła Stadnicka-Kozłowska, Mariusz Thomas, Alina Dauksza-Wiśniewska (fotograf) oraz ogrodniczki 
Wiesława Dudzińska i Lilia Kowalska. Wszystkie te osoby są członkami działającymi z ramienia ToMiTo. Członkowie komisji dokonali oceny zgłoszonych obiektów w dniach od 3 do 20 lipca 2018 r. Zakończenie konkursu, które odbyło się 12 października 2018 r. w Sali Mieszczańskiej Ratusza Staromiejskiego, było wspólnym podsumowaniem dwóch konkursów „Toruń w kwiatach 2018” oraz konkursu ogłoszonego przez prezydenta miasta „Toruń ogrodem". W trakcie ceremonii, którą prowadził, jak zawsze sprawnie, wiceprezes ToMiTo Michał Targowski, a nagrody wręczali prezydent Torunia Michał Zaleski wraz z Krzysztofem Mikulskim, można było oglądać fotografie nagrodzonych pięknych balkonów i roślinności w ogrodach - wykonane przez Alinę Daukszę-Wiśniewską. Prezydent Torunia serdecznie podziękował uczestnikom konkursu oraz pozował z nagrodzonymi do pamiątkowych zdjęć.

Wspólnie z Urzędem Miasta kontynuowano prace nad przeglądem i rejestracją mogił osób zasłużonych dla Torunia. W ramach prac konserwatorskich przy zniszczonych nagrobkach na cmentarzu św. Jerzego, ze środków publicznych zebranych podczas zbiórki publicznej-kwesty 1 listopada 2017 r., odrestaurowano nagrobek Antoniego Ignacego Żernickiego, kapitana wojska pruskiego, poborcy podatkowego i dyrektora urzędu celnego w Sicienku oraz dziedzica włości w Rubinkowie i Biskupicach. Podjęliśmy także akcję ratunkową uszkodzonego przez wichurę nagrobka Heliodora Marjana Barałkiewicza. Ze względu na wzrastającą liczbę odnowionych kwater i upływający czas od ich odrestaurowania część środków pieniężnych przeznaczona została na bieżącą opiekę nad nimi.

W trakcie XVI kwesty na cmentarzu św. Jerzego przy ul. Gałczyńskiego Toruniu, w dniu 1 listopada 2018 r., kwestowało więcej osób niż w ubiegłych latach, bo aż 80, byli wśród nich członkowie Zarządu ToMiTo i Bractwa Kurkowego, członkowie Zarządu Miasta wraz z prezydentem Michałem Zaleskim i wiceprezydentami Zbigniewem Fiderewiczem, Andrzejem Rakowiczem, Zbigniewem Rasielewskim oraz z przewodniczącym Rady Miasta Marcinem Czyżniewskim. Kwestowali przedstawiciele władz samorządowych, m.in. marszałek województwa Piotr Całbecki i sekretarz województwa Marek Smoczyk, a także dziennikarze, sportowcy, marynarze z patronackiego okrętu ORP Toruń, strażacy. Nie zabrakło przedstawicieli nauki i kultury z rektorem UMK prof. Andrzejem Tretynem. Wśród kwestujących znaleźli się też: Anna Bogłowska, Magdalena Cynk, Andrzej Churski, Iwona Michałek, Arkadiusz Myrcha, Wojciech Polak, Stanisław Rakowicz, Marek Rubnikowicz, Przemysław Termiński, Dorota Zawacka-Wakarecy. Na renowację zniszczonych nagrobków na cmentarzu zebrano kwotę 22 001,80 zł. Ofiarodawcom wręczano kolorowy folder $\mathrm{z}$ opisem odnowionych nagrobków. O tradycjach toruń- 
skiego kwestowania, zainicjowanych i przeprowadzanych przez członków ToMiTo, przypomniano w wiadomościach przed Świętem Zmarłych w ,Zbliżeniach" TV Bydgoszcz oraz programach TV Toruń, także w rozmowie dnia, której gościem był Arkadiusz Kierys.

$\mathrm{Na}$ zlecenie Gminy Miasta Toruń dokonano inwentaryzacji zaniedbanych i cennych architektonicznie nagrobków na cmentarzu św. Jerzego w Toruniu. Prace pod kierunkiem wiceprezesa Michała Targowskiego przeprowadzono, by stworzyć internetową bazę nagrobków zasługujących na szczególną uwagę i rekonstrukcję.

Członkowie Zarządu Krzysztof Kopiński, Cecylia Iwaniszewska i Katarzyna Tomkowiak współpracowali z Komisją Polityki Społecznej i Zdrowia oraz Kultury i Promocji Rady Miasta w sprawach dotyczących nazewnictwa ulic i placów. Zaopiniowano projekt sformalizowania procedury nazewnictwa ulic w mieście (niestety nie trafił pod obrady) oraz 7 wniosków w sprawie nazewnictwa ulic. Cecylia Iwaniszewska i Katarzyna Tomkowiak 15 listopada 2018 r. wzięły udział w uroczystości poświęconej toruńskiej rodzinie Torwirtów oraz nadaniu ich imienia skwerowi przy tzw. Grzybku; reprezentowały też Komisję nazewnictwa ulic ToMiTo przy Radzie Miasta.

W okresie sprawozdawczym Towarzystwo wspierało wiele inicjatyw lokalnych, m.in. przekazano wydawnictwa ToMiTo na nagrody w Wojewódzkim Konkursie Katarzynkowym, organizowanym przez Oddział Przewodnicki PTTK dla dzieci, a członkowie ToMiTo wzięli udział w uroczystości wręczenia nagród w dniu 7 grudnia 2018 r. w auli I LO w Toruniu.

Wydawnictwa ToMiTo przeznaczono też na nagrody dla dzieci w Konkursie Mikołajkowym, organizowanym przez Koło ToMiTo Podgórz (uroczystości w dniu 4 grudnia 2018 r.) oraz na nagrody dla uczestników konkursu XIX edycji Miejskiego Konkursu Historycznego „Dzieje Torunia”, którego organizatorem jest Zespół Szkół Przemysłu Spożywczego i VIII Liceum Ogólnokształcące w Toruniu; finał konkursu odbył się 23 marca 2018 r. Towarzystwo współpracowało z Oddziałem Przewodnickim PTTK w Toruniu. Tradycyjnie w dniu Walnego Zebrania Towarzystwa prezes K. Mikulski wręczył wyróżnienie „Przewodnik Roku 2018”, otrzymała je Lucyna Gajewska.

\section{Popularyzowanie wiedzy o Toruniu}

Przeprowadzono XXVII konkurs na prace magisterskie i dyplomowe poświęcone Toruniowi. Uroczyste zakończenie odbyło się w dniu 6 marca 2019 r. w Sali Rady Ratusza Staromiejskiego, na które przybył wiceprezydent Torunia Andrzej Rakowicz. W skład komisji oceniającej prace wchodzili: przewodniczący - Krzysztof Kopiński oraz członkowie - Agnieszka Zielińska i Piotr Birecki. 
Konkurs miał charakter ogólnopolski. Przyznano następujące nagrody i wyróżnienia:

- z zakresu ochrony dóbr kultury:

III nagroda - Rafał Powązka za pracę magisterską „Zakład przemysłowy »Born \& Schütze« w Toruniu. Jego dzieje i problematyka konserwatorska",

III nagroda - ks. Grzegorz Grąbczewski za pracę licencjacką „Pałac w Przysieku - jego historia i problematyka konserwatorska",

wyróżnienie - Alicja Graczyk za pracę licencjacką „Zespół średniowiecznych witraży z Muzeum Okręgowego w Toruniu. Problematyka historycznoartystyczna, zabytkoznawcza i konserwatorska",

wyróżnienie - Anna Kaprzyk za pracę licencjacką „Dworzec Główny PKP w Toruniu - jego historia i problematyka konserwatorska”,

- z zakresu architektury i urbanistyki:

II nagroda - Marcin Furmański za pracę magisterską „Koncepcja architektoniczna kościoła rzymskokatolickiego na osiedlu JAR w Toruniu",

III nagroda - Patrycja Stacherska za pracę dyplomową inżynierską „Koncepcja zagospodarowania przestrzennego terenu położonego pomiędzy ulicami Kościuszki, Chrobrego i Batorego w Toruniu",

- z zakresu historii:

I nagroda - Maciej Stawiski za pracę magisterską „,Fundatorska i duszpasterska działalność bernardynów toruńskich w latach 1724-1772",

III nagroda - Włodzimierz Deczyński za pracę licencjacką „Kształtowanie nazewnictwa istniejących i nowo powstałych ulic toruńskiego osiedla Bielany w dwudziestoleciu międzywojennym",

III nagroda - Dorota Wolniszewska za pracę licencjacką „Życie codzienne Bydgoskiego Przedmieścia w okresie XX-lecia międzywojennego w świetle lokalnej prasy",

wyróżnienie - Michał Tokarczyk za pracę licencjacką „Bezrobocie w Toruniu w czasach Wielkiego Kryzysu (1929-1933)",

- z zakresu kulturoznawstwa:

I nagroda - Klaudia Peplińska za pracę magisterską „Metamorfozy Bydgoskiego Przedmieścia $\mathrm{w}$ Toruniu. Wybrane problemy rewitalizacji i metody pracy ze społecznością lokalną",

- z zakresu geoinformacji:

I nagroda - Dominika Karpińska za pracę magisterską „Analiza zanieczyszczenia świetlnego nocnego nieba na przykładzie Torunia i okolic".

Łącznie przyznano trzy nagrody pierwsze, jedną nagrodę drugą, pięć trzecich oraz trzy wyróżnienia. Konkurs objęty jest honorowym patronatem prezydenta miasta Torunia Michała Zaleskiego. O konkursie, jego laureatach, 
uwzględnieniu prac z terenu całej Polski w rywalizacji o laur najlepszych prac o Toruniu mówił dla TV Toruń wiceprezes ToMiTo Michał Targowski.

Popularyzacji wiedzy o Toruniu służyły organizowane przez Towarzystwo Miłośników Torunia i Książnicę Kopernikańską wykłady i prelekcje w ramach „Wieczorów Toruńskich” i inne spotkania w bibliotece. Często towarzyszyły im również wystawy nawiązujące do tematyki spotkań organizowane w siedzibie Książnicy Kopernikańskiej przy ulicy Słowackiego 8. Odbyły się następujące wieczory, sesje i spotkania:

7 czerwca - poświęcony Ludwikowi Makowskiemu, spotkanie z Ewą Gawrońską i Katarzyną Tomkowiak, „Ludwik Makowski - torunianin, patriota, chórzysta i krawiec”, wieczorowi towarzyszył występ chóru „Lutnia” (wieczór zorganizowany wraz z Książnicą Kopernikańską);

5 lipca w Roku Anny Wazówny, córki Jana III Wazy i Katarzyny Jagiellonki, zorganizowano sesję w 450 rocznicę jej urodzin, miejscem wieczoru była kaplica ewangelicko-augsburska (przy ul. Strumykowej): „Anna Wazówna i jej toruński grobowiec". Wykład wygłosiła dr Alicja Saar-Kozłowska. Podczas spotkania nastąpiło uroczyste wręczenie Złotego Astrolabium - honorowego wyróżnienia Towarzystwa prof. dr. hab. Januszowi Małłkowi. Organizatorami wydarzeń prócz Towarzystwa Miłośników Torunia były Parafia Wniebowzięcia Najświętszej Marii Panny i bł. ks. Stefana W. Frelichowskiego, Parafia Ewangelicko-Augsburska w Toruniu oraz Książnica Kopernikańska w Toruniu.

18 października Towarzystwo włączyło się w zorganizowanie sesji popularnonaukowej „Niepodległa w kulturze. Kultura Kujaw i Pomorza w okresie międzywojennym”, którą zorganizowała Książnica Kopernikańska. Na sesję przybyło wyjątkowo wielu uczestników (przeszło 150 osób).

29 listopada odbył się wieczór poświęcony dr Cecylii Iwaniszewskiej w 90. rocznicę urodzin, zatytułowany „Nieprzeciętna Kobieta Pani Profesor Cecylia Iwaniszewska". O jubilatce mówiły Magdalena Łubieńska i Katarzyna Tomkowiak. Spotkanie zorganizowano wraz z Książnicą Kopernikańską, Polskim Towarzystwem Miłośników Astronomii, Stowarzyszeniem Absolwentów UMK, Towarzystwem Śpiewaczym „Lutnia”. Jubilatkę obdarowano wydanym w jednym egzemplarzu okolicznościowym albumem Kobieta niezwykła Cecylia Maria z Łubieńskich Iwaniszewska, pod red. Aliny Daukszy-Wiśniewskiej i Katarzyny Tomkowiak; na spotkanie przybyło 156 osób. Jubilatka została uhonorowana przez marszałka Piotra Całbeckiego Medalem Marszałka Województwa Kujawsko-Pomorskiego z okazji 100 lat Niepodległości.

2 kwietnia Towarzystwo uczciło pamięć Zefiryna Jędrzyńskiego, długoletniego członka i redaktora swych wydawnictw. Wieczór toruński i jednocześnie 
wieczór bibliofilski pt. „Zefiryn Jędrzyński. We wspomnieniach przyjaciół”, zorganizowano w Książnicy Kopernikańskiej. Po przypomnieniu sylwetki tego zacnego torunianina przez Katarzynę Tomkowiak głos zabrali jego przyjaciele: Czesław Niedzielski, długoletni przyjaciel i równolatek bohatera wieczoru, a także Cecylia Iwaniszewska czy aktor sceny toruńskiej Witold Tokarski. Przybyło około 70 osób, a organizatorami prócz ToMiTo byli komilitoni z Towarzystwa Bibliofilów im. J. Lelewela w Toruniu oraz Książnica Kopernikańska. Rozmowom po wieczorze nie było końca.

16 maja, przed Walnym Zebraniem, Katarzyna Tomkowiak przedstawiła drugie wydanie swej książki - która jest wspólnym wydawnictwem Towarzystwa i Książnicy Kopernikańskiej w Toruniu - Biblioteki w Toruniu i Podgórzu w latach 1920-1939 (wydanie II poprawione,Torun 2019).

Informacje o Wieczorach Toruńskich zamieszczano w „Ikarze”, toruńskim dzienniku „Nowości”, witrynie internetowej Książnicy Kopernikańskiej, stronach FB ToMiTo i Książnicy Kopernikańskiej. Zapowiedzi i relacje z wieczorów ukazały się także w lokalnych wydaniach „Aktualności Toruńskich” TV Toruń oraz na blogu Działu Informacyjno-Bibliograficznego Książnicy Kopernikańskiej. Relację z Wieczorów Toruńskich można było zobaczyć także w „Bulwarze sztuki” red. Ewy Jarczyk z TV Toruń oraz w „Zbliżeniach” TV Bydgoszcz (najczęściej w dniu imprezy).

W ramach cyklu konkursowego „Czy znasz Toruń?” w roku 2017 rozszerzyliśmy konkurs o grupę najmłodszych uczestników. We współpracy z Książnicą Kopernikańską w Toruniu włączyliśmy się do organizacji edycji specjalnej konkursu - gry miejskiej. Wystartowała ona pod tytułem „Zagadkowa Książnica", a pytania i zadania związane były nie tylko z rocznicą i historią tej zacnej niegdyś miejskiej biblioteki, ale także z Mikołajem Kopernikiem. Konkurs-gra miejska został przygotowany przez pracowników Książnicy: Agnieszkę Ignaszak, Aleksandrę Martini-Surman, Marcina Pejkowskiego, Emilię Raczkowską, Monikę Wróblewską, Magdalenę Zielińską. Konkurs trwał od 7 do 26 maja 2018 r. (czyli jego początek przypadł w poprzednim roku sprawozdawczym), a jego rozstrzygnięcie nastąpiło 26 maja 2018 r. Grze miejskiej towarzyszyła duża akcja promocyjna - m.in. rozprowadzono 250 specjalnych plakatów z okolicznościowym znakiem graficznym gry oraz z logo ToMiTo. Gra została zorganizowana $w$ ramach obchodów 95. rocznicy powstania Książnicy Kopernikańskiej. Do zadań uczestników należało rozwiązywanie łamigłówek i zadań o charakterze edukacyjnym oraz spacer po centrum Torunia szlakiem miejsc związanych z historią Książnicy Kopernikańskiej i wykonanie dla niej oryginalnej kartki urodzinowej. W dniach 29-30 maja dokonano oceny tych zadań, w tym także przygotowanych przez uczestników kart urodzi- 
nowych. Wyniki zamieszczono 4 czerwca na stronie internetowej biblioteki. Uroczyste zakończenie i wręczenie nagród odbyło się w Książnicy przy ul. Słowackiego podczas ogólnopolskiej akcji „Noc w Bibliotece”. W grze wzięło udział 347 uczestników. W sumie przyznano po trzy nagrody główne w każdej kategorii, czyli 15. Laureaci pierwszych miejsc otrzymali tablety, a wyróżnieni - wejściówki i vouchery, natomiast wszystkich obdarowano słodyczami - regionalnymi wyrobami, także z naszego miasta. Nagrody wręczały wicedyrektor biblioteki Sylwia Furgała oraz członkini Zarządu Towarzystwa Cecylia Iwaniszewska.

4 grudnia 2018 r. kolejna edycja konkursu „Czy znasz Toruń?” została przeprowadzona podczas imprezy mikołajkowej organizowanej przez Dom Muz na Podgórzu, współorganizatorami byli członkowie z Koła ToMiTo Podgórz.

Informacje o konkursach i organizowanych spotkaniach ToMiTo umieszczane były na łamach lokalnej prasy (głównie w toruńskim dzienniku „Nowości” i miejskim informatorze „Ikar”) oraz na stronie internetowej www.tomito. cba.pl, Książnicy Kopernikańskiej www.ksiaznica.torun.pl, na facebooku ToMiTo i profilu FB Książnicy Kopernikańskiej, na blogu Działu InformacyjnoBibliograficznego Książnicy Kopernikańskiej, który prowadzi Grzegorz Barecki, a także w formie krótkiej notatki i linku na stronach Towarzystwa Bibliofilów im. Joachima Lelewela w Toruniu http://www.bibliofile.torun.pl/joomla/ (tam zamieszczała je dr hab. Wanda Ciszewska, członek TBL oraz Rady Naukowej Książnicy Kopernikańskiej). Media lokalne często zapowiadały i relacjonowały wydarzenia ToMiTo i Książnicy Kopernikańskiej, m.in. informacje te podawano w programie red. Ewy Jarczyk „Bulwar Sztuki” (który jest wydawany, jako program TV Toruń, ale ma też swe wydanie internetowe).

W dniach 27-28 września 2018 r. Towarzystwo Miłośników Torunia uczestniczyło jako współorganizator w ogólnopolskiej konferencji naukowej „100 lat teatru w Toruniu”. Wydarzenie zainicjował i zorganizował Teatr im. Wilama Horzycy, odbyła się wówczas debata o stuletnich dziejach polskiej sceny w Toruniu oraz życiu teatralnym naszego miasta.

Towarzystwo wspomagało prace okolicznościowej stacji krótkofalarskiej promującej wydarzenia i miasto Toruń oraz region toruński wśród kilkuset nadawców i nasłuchowców w kraju i za granicą w czasie pracy stacji Klubu Krótkofalowców Polskiego Związku Krótkofalowców FORT IV przy ToMiTo. Tradycyjnie już klubowicze pracowali na falach eteru pod znakiem klubowym SP2TMT. Szczególne zainteresowanie wzbudziła działalność stacji okolicznościowej w związku z przypadającą w 2018 r. 80. rocznicą zdobycia przez polskich pilotów balonowych prestiżowego Pucharu Gordona Bennetta (jesie- 
nią 1938 r.). Temu wydarzeniu poświęcona została praca stacji okolicznościowej o znaku HF80PGB.

W dniu 14 grudnia 2017 r. powstał trzyosobowy Komitet Odbudowy Pomnika Wojsk Balonowych, jego przewodniczącym został red. Andrzej Szmak, a członkami Michał Targowski i Mariusz Thomas. Komitet w omawianym roku sprawozdawczym kontynuował prace mające na celu rekonstrukcję pomnika wojsk balonowych w parku na Bydgoskim Przedmieściu. Przygotowano wniosek do Rady Miasta Torunia w sprawie wyrażenia zgody na odbudowę tego pomnika. Uchwała została podjęta przez Radę Miasta 18 października 2018 r. Uzyskano wsparcie finansowe gdańskiego oddziału IPN w wysokości 90000 złotych z przeznaczeniem na rekonstrukcję rzeźby orła ze zwieńczenia pomnika. Wykonawcą rzeźby, wyłonionym przez IPN w drodze naboru ofert, jest toruński artysta Maciej Jagodziński-Jagenmeer. Prace nad jej rekonstrukcją, prowadzone pod nadzorem wojewódzkiego konserwatora zabytków Sambora Gawińskiego, zostaną zakończone latem 2019 r. Za zgodą dyrektora Muzeum Okręgowego Marka Rubnikowicza rzeźba orła będzie eksponowana na dziedzińcu toruńskiego Ratusza od września br. do czasu odsłonięcia pomnika. Rozpoczęta w poprzednim roku zbiórka na odbudowę pomnika przyniosła do końca kwietnia 2019 r. kwotę 9700 złotych, w znacznej części były to wpłaty z zagranicy. Członkowie Komitetu uzyskali zapewnienie wsparcia logistycznego w zakresie robót budowlanych i montażowych związanych z posadowieniem pomnika przez toruńską firmę „Budtech” o szacunkowej wartości 40000 zł. Współpracowali także z Urzędem Miasta Torunia w zakresie przygotowania dokumentacji niezbędnej do ubiegania się o wsparcie finansowe ministra kultury i dziedzictwa narodowego oraz ministra obrony (w obu przypadkach wniosek o dotację może złożyć wyłącznie Gmina Miasta Toruń jako właściciel miejsca, na którym stanie pomnik). Poza tym zainicjowali powołanie Komitetu Honorowego Odbudowy Pomnika z udziałem wicepremiera-ministra kultury i dziedzictwa narodowego, ministra obrony narodowej, szefa Urzędu ds. Kombatantów i Osób Represjonowanych, dyrektora gdańskiego oddziału IPN, prezydenta miasta Torunia, prezesa Aeroklubu RP, biskupa toruńskiego. Został również przygotowany program wydarzeń popularnonaukowych, artystycznych i sportowych związanych z odbudową pomnika i uroczystością jego odsłonięcia. Na stronie internetowej ToMiTo, portalach społecznościowych, w prasie lokalnej i krajowej, w czasopismach i wydawnictwach o tematyce historycznej promowano ideę odbudowy pomnika i wydarzeń towarzyszących. Członkowie Komitetu współpracowali przy tworzeniu scenariusza filmu dokumentalnego realizowanego przez TVP. Opracowano i wydrukowano ulotki informacyjne na temat rekonstruowanego 
pomnika i zbiórki pieniężnej na jego odbudowę. Redaktor Andrzej Szmak wystąpił i zachęcał do ofiarności na ten cel zarówno w „Zbliżeniach” TV Bydgoszcz, jak i programach TV Toruń, w tym w „Rozmowie dnia” codziennie emitowanej w tej lokalnej telewizji.

\section{Wydawanie publikacji związanych z dziejami Torunia}

W okresie sprawozdawczym Towarzystwo opublikowało $z$ pomocą finansową Gminy Miasta Toruń następujące wydawnictwa:

- 45 tom „Rocznika Toruńskiego”, pod redakcją Agnieszki Zielińskiej; ukazał się w nakładzie 300 egzemplarzy, zawiera 17 autoryzowanych artykułów, jest wydawany w porozumieniu z UMK;

- Biblioteki w Toruniu i Podgórzu w latach 1920-1939, autorstwa Katarzyny Tomkowiak, druk w nakładzie 150 egzemplarzy w 2018 r.; przy współudziale Książnicy Kopernikańskiej II wydanie poprawione w nakładzie 100 egzemplarzy;

- opracowanie wydawnictwa Wierność $i$ stałość $w$ ogniu wypróbowana... Oblężenia Torunia w XVII i XVIII wieku - Arkadiusz Bożejewicz i Marcin Sobiech, nakład 200 egzemplarzy; oraz

- kolorowy okolicznościowy folder przygotowany przez Arkadiusza Kierysa z okazji kwesty na cmentarzu w dniu 1 listopada, wydany wspólnie z Urzędem Miasta Torunia.

Do 8 tomu TSB przyjęto 70 opracowanych haseł - biogramów.

Promocja 45 tomu „Rocznika Toruńskiego” i innych wydawnictw ToMiTo odbyła się w 21 lutego 2019 r. w Książnicy Kopernikańskiej; imprezie towarzyszyła wystawa „Kolekcja historyczna ze zbiorów Włodzimierza Deczyńskiego" - wydarzenie cieszyło się dużym zainteresowaniem, odnotowano także rekordową sprzedaż „Rocznika”. Wystawę W. Deczyńskiego, która będzie eksponowana w bibliotece do 29 maja obejrzało już prawie 500 osób. Sam autor i jednocześnie właściciel kolekcji oprowadził po niej pięć grup. Byli to studenci z WNH UMK oraz uczestnicy zajęć z Kamienicy Inicjatyw w Toruniu (5 kwietnia 2019 r.). To właśnie oni pięknie opisali zajęcia prowadzone podczas wystawy, a także opowieści W. Deczyńskiego, na stronach swego portalu internetowego MywToruniu, zamieszczono tam również dokumentację fotograficzną wizyty autora w Książnicy.

Wszystkie wydawnictwa Towarzystwa znalazły się w sprzedaży na VII Kiermaszu Książki Regionalnej, który odbył się 13 maja 2019 r. w Bibliotece Uniwersyteckiej w Toruniu (przy stoisku ToMiTo dyżury pełniły Elżbieta Thomas i Joanna Danuta Horyza). Warto nadmienić, iż w trakcie kiermaszu odbyło się spotkanie autorskie z Katarzyną Tomkowiak. Rozmawiał z nią 
Michał Targowski, a tematem była jej praca Biblioteki w Toruniu i Podgórzu w latach 1920-1939 (wyd. II), natomiast w styczniu 2019 r. redaktor Ewa Jarczyk reklamowała tę książkę (wyd. I) w programie TV Toruń.

W związku z przygotowaniami do obchodów 100. rocznicy powrotu Torunia do wolnej Polski, przypadającej 18 stycznia 2020 r., Urząd Miasta Torunia powołał komitet roboczy koordynujący organizację imprez $\mathrm{z}$ tej okazji. Z ramienia Towarzystwa, na prośbę prezydenta miasta Torunia, do uczestnictwa w pracach komitetu powołano Michała Targowskiego i Jarosława Kłaczkowa.

$\mathrm{Na}$ zakończenie sprawozdania $\mathrm{z}$ działalności Towarzystwa Miłośników Torunia pragniemy podziękować za pomoc udzieloną nam przez liczne instytucje: władze miasta Torunia z prezydentem Michałem Zaleskim i przewodniczącym Rady Miasta Marcinem Czyżniewskim, Uniwersytet Mikołaja Kopernika z rektorem prof. dr. hab. Andrzejem Tretynem, Wojewódzką Bibliotekę Publiczną-Książnicą Kopernikańską z dyrektor Danettą Ryszkowską-Mirowską, Muzeum Okręgowe z dyrektorem Markiem Rubnikowiczem, Biuro Miejskiego Konserwatora Zabytków z dyrektorem Emanuelem Okoniem, Polskie Zrzeszenie Inżynierów i Techników Sanitarnych Oddział Toruń z Jerzym Piotrowiakiem, Muzeum Etnograficzne im. Marii Znamierowskiej-Prüfferowej, Fundację „Zamek Dybów i Gród Nieszawa”, Fundację Generał Elżbiety Zawackiej, Wydawnictwo Adam Marszałek, Drukarnię TOTEM, Drukarnię Machina Druku, Dom Muz, Archiwum Państwowe w Toruniu, PTTK - Oddział Przewodnicki, Towarzystwo Bibliofilów im. J. Lelewela w Toruniu oraz redakcję „Nowości”. Niezawodną pomoc w czasie organizowania konkursu „Torun w kwiatach” okazywały nam firmy „Patio” i „Skwer”. Serdeczne podziękowania kierujemy także do dwóch toruńskich parafii: EwangelickoAugsburskiej w Toruniu, na ręce ks. proboszcza Michała Walukiewicza, i Wniebowzięcia Najświętszej Marii Panny i bł. ks. Stefana W. Frelichowskiego, na ręce ks. proboszcza Wojciecha Niedźwieckiego.

Nasze podziękowania pragniemy również przekazać wszystkim osobom, które w dniu 1 listopada cierpliwie krążyły po cmentarnych dróżkach, zbierając datki przeznaczone na renowację zniszczonych nagrobków, a wszystkim ofiarodawcom pięknie dziękujemy.

Katarzyna Tomkowiak (Toruń) 



408 

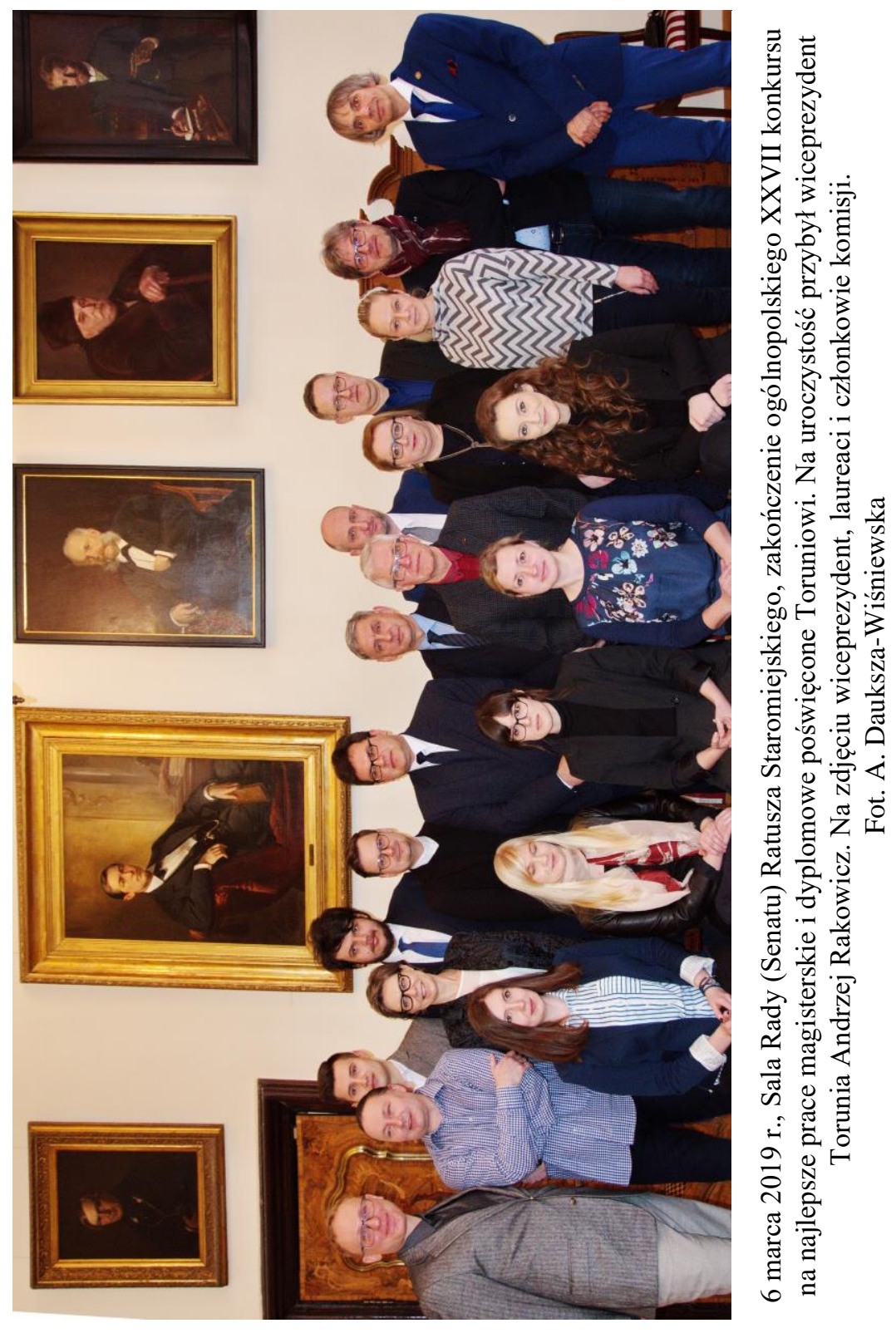